\title{
Effects of polyethylene IUDs and unilateral ovariectomy in golden hamsters
}

\author{
R. J. Hodosh* and H. Magalhaes \\ Department of Biology, Bucknell University, Lewisburg, Pennsylvania 17837, U.S.A.
}

The antifertility action of intrauterine devices (IUDs) differs from species to species (Chang, Tatum \& Kincl, 1970). In rats, silk suture or polyethylene IUDs reduce or eliminate implantation only in the horn containing the device, whereas in mice implantations are prevented in both uterine horns (Corfman \& Segal, 1968; Bannergee \& Massie, 1969; Marston \& Kelly, 1969; Bo \& Krueger, 1972; Bo, Krueger \& Garrison, 1972). As in rats, silk suture IUDs in hamsters have a unilateral effect (Orsini, 1965; Richardson \& Ansbacher, 1971), but the effect of polyethylene IUDs has not been reported for hamsters.

Unilateral ovariectomy in rats and hamsters results in an increase in the number of ova released from the remaining ovary (Grady \& Greenwald, 1968; Peppler \& Greenwald, 1970; Peppler, 1971; Joshi \& Labhsetwar, 1973). We therefore studied the effects of unilateral ovariectomy and polyethylene IUDs in hamsters.

\section{Methods}

Golden hamsters (Mesocricetus auratus) of the 'e' strain from the Bucknell University colony were 2.5-8.5 months of age when studied. The 19 males were all proven sires and the 60 females had each given birth to at least one litter. The animals were housed in the main hamster colony room in individual cages $(18 \times 24 \times 17.5 \mathrm{~cm})$. Incandescent lights provided illumination from 07.30 to $22.30 \mathrm{~h}$ and food and water were always available.

Animals were anaesthetized by i.p. injection of $0.25 \mathrm{ml}$ sodium pentobarbitol (Diabutal, 60 $\mathrm{mg} / \mathrm{ml}$ : Diamond Laboratories, Des Moines, Iowa) $/ 100 \mathrm{~g}$ body weight. Six different operative procedures were then performed unilaterally on one ovary or one horn per animal, leaving the contralateral horn for comparison. The six groups were (1) insertion of an IUD, (2) ovariectomy, (3) IUD + ovariectomy, (4) sham IUD, (5) sham ovariectomy, and (6) sham IUD + ovariectomy, and there were 10 females in each group.

The IUDs were made of polyethylene tubing (i.d. $0.028 \mathrm{~cm}, 0 . \mathrm{d} .0 .061 \mathrm{~cm}$ : Clay Adams, Parsippany, New Jersey). Each IUD was inserted through the uterine wall into the ovarian end of the uterus using the method of Bo et al. (1972). About $1.5 \mathrm{~cm}$ of tubing were left within the lumen of the uterus. At ovariectomy all ovarian tissue was removed on one side only. In Group 3 the IUD was inserted before removal of the ipsilateral ovary. For the sham-IUD operation the tubing was inserted and then quickly removed; sham ovariectomy consisted of merely touching the ovary with a metal probe.

Preliminary observations had indicated that different positions of the polyethylene IUD in hamsters have equal antifertility effect: there were no implantations when the IUD was inserted at either end or in the middle of the uterine horn. Therefore, a single location was selected for positioning all experimental IUDs.

The animals were paired 1 week after the operation and killed with chloroform 2 weeks after mating. Implantations in each uterus were counted and their sizes were estimated with a screw head template (No. 3220: $\mathrm{KOH}-\mathrm{I}-\mathrm{NOOR}$ ). The uteri were placed in $0.85 \%(\mathrm{w} / \mathrm{v}) \mathrm{NaCl}$ solution and the embryos removed. Embryos were considered living if they showed a heartbeat or muscle movement. The total numbers of implantations and live embryos were compared by a two-way analysis of variance (ANOVA), with Tukey's Method for Multiple Comparisons (Guenther, 1964).

\section{Results and discussion}

The presence of an IUD or the removal of an ovary completely blocked pregnancy in the uterine horn on that side (Table 1). The three sources of variance all contributed significantly to the total

* Present address: Department of Zoology, University of Maine, Orono, Maine 04473, U.S.A. 
number of implantations $(F=8 \cdot 35$, d.f. $=5,108, P<0 \cdot 01$ for the six operation groups; $F=322 \cdot 14$, d.f. $=1,108, P<0.01$ for the two uteri, operated and contralateral; $\mathrm{F}=29.08$, d.f. $=5,108, P<0.01$ for the interaction). The values for the live embryos were also significant $(F=6.03$, d.f. $=5,108$, $P<0.01$ for the operation groups; $F=152.44$, d.f. $=1,108, P<0.01$ for the uteri; $F=15.48$, d.f. $=5,108, P<0.01$ for the interaction).

Table 1. Mean ( \pm S.E.M.) number of total implantations and live embryos of hamsters (10/group) after various operative procedures to one ovary or horn of the uterus

\begin{tabular}{|c|c|c|c|c|c|c|}
\hline & \multicolumn{6}{|c|}{ Group } \\
\hline & $\begin{array}{c}1 \\
\text { (IUD) }\end{array}$ & $\stackrel{2}{(O V X)}$ & $\begin{array}{c}3 \\
(I U D+O V X)\end{array}$ & $\stackrel{4}{4}$ & $\stackrel{5}{\text { (sham OVX) }}$ & $\stackrel{6}{(\text { sham IUD }+ \text { OVX) }}$ \\
\hline No. of animals & 10 & 10 & 10 & 10 & 10 & 10 \\
\hline $\begin{array}{l}\text { Side of operation } \\
\text { No. of embryos } \\
\text { No. live }\end{array}$ & $\begin{array}{l}0 \\
-\end{array}$ & $\underline{0}$ & $\underline{0}$ & $\begin{array}{l}4.4 \pm 0.83 \ddagger \\
2.9 \pm 0.65 \ddagger\end{array}$ & $\begin{array}{l}6.4 \pm 0.70 \\
5.9 \pm 0.66\end{array}$ & $\begin{array}{l}4.7 \pm 0.73 \\
3.7 \pm 0.62\end{array}$ \\
\hline $\begin{array}{l}\text { Contralateral horns } \\
\text { No. of embryos } \\
\text { No. live }\end{array}$ & $\begin{array}{l}7.5 \pm 0.43 \\
6.0 \pm 0.63\end{array}$ & $\begin{array}{l}9.6 \pm 0.67^{*} \\
6.9 \pm 0.81\end{array}$ & $\begin{array}{l}9 \cdot 6 \pm 0.37^{*} \\
7 \cdot 3 \pm 0.58\end{array}$ & $\begin{array}{l}7.8 \pm 0.57 \\
5.7 \pm 0.75\end{array}$ & $\begin{array}{l}7 \cdot 1 \pm 0.48 \\
5.8 \pm 0.55\end{array}$ & $\begin{array}{l}6.4 \pm 0.22 \\
4.8 \pm 0.47\end{array}$ \\
\hline $\begin{array}{l}\text { Means/uterine horn } \\
\text { No. of embryos } \\
\text { No. live }\end{array}$ & $\begin{array}{l}3.8 \pm 0.36 \dagger \\
3.0 \pm 0.53\end{array}$ & $\begin{array}{l}4.8 \pm 0.56 \dagger \\
3.5 \pm 0.68\end{array}$ & $\begin{array}{l}4 \cdot 8 \pm 0.31 \\
3.7 \pm 0.48\end{array}$ & $\begin{array}{l}6 \cdot 1 \pm 0 \cdot 91 \\
4 \cdot 3 \pm 1 \cdot 01\end{array}$ & $\begin{array}{l}6.8 \pm 0.91 \\
5.8 \pm 0.59\end{array}$ & $\begin{array}{l}5.6 \pm 0.73 \\
4.3 \pm 0.78\end{array}$ \\
\hline
\end{tabular}

* These values significantly greater $(P<0.05)$ than those in corresponding sham operation groups. $\dagger$ These values significantly lower $(P<0.05)$ than those in the corresponding sham operation groups. $\ddagger$ These values significantly lower $(P<0.05)$ than those in the contralateral uterine horn.

There were no significant differences between the effects of any operation with respect to the sizes of the implantations and live embryos.

In 13 of the 20 hamsters with IUDs (Groups 1 and 2) an exudate, found in uteri with or without associated ovary, was located near the area containing the IUD. In some animals the exudate filled the entire uterus, but none was ever found in the contralateral uterus or in the vagina. The exudate was viscous and gray to brown in colour, not the characteristic yellow of pus.

Intrauterine devices have been used for many years as a means of controlling fertility in different species. The present study indicates that hamsters respond to unilateral polyethylene IUDs in a distinctive manner. Like the silk suture (Orsini, 1965; Chang et al., 1970; Richardson \& Ansbacher, 1971), the polyethylene IUD completely blocks pregnancy in the uterus in which it is inserted but does not reduce fertility in the contralateral uterus. In mice, however, there is a decrease in the number of implantations in the contralateral horn (Marston \& Kelly, 1969), and in rats the IUD-containing uterus can support implantations (Bo et al., 1972; Bo \& Krueger, 1972).

Previous investigators have not described the formation of exudate in hamsters as a response to an IUD, but in rats a visible accumulation of fluid was noted in $54 \%$ of the IUD-containing uteri (Wrenn, Wood \& Bitman, 1968). El Sahwi \& Moyer (1971) noted that the antifertility action of a silicone-plastic IUD was in proportion to the number of leucocytes observed in the uterine lumen. However, studies with induced neutropaenia in rats suggested that inflammation plays a very minor role in the antifertility action of the IUD (Shulton, Lobl \& Ward, 1975). Increased levels of immunoglobulin $\mathrm{G}$ and other presumed embryotoxic substances in the lumen of the uterus have also been reported (Holub, 1972; Mackay \& Breed, 1972). Because contraception occurred in the absence of a visible exudate, we believe the exudate is not involved in the mechanism of action of polyethylene IUDs.

Compensatory ovulation, i.e. an increase in the number of ova released from the remaining ovary after unilateral ovariectomy to give a total of about the number released by both ovaries, appears to be the result of a decrease in the level of gonadal hormones and a consequent increase in gonado- 
trophin release which stimulates release of additional ova from the remaining ovary (Greenwald, 1968). In the hamsters fitted with an IUD and ovariectomized (Group 3), the numbers of implantations in the contralateral horn were equivalent to those in hamsters subjected only to ovariectomy (Group 2), suggesting that the IUD did not counteract the compensatory ovulation caused by the unilateral ovariectomy. The compensatory ovulation did not result in increased numbers of live young.

A two-fold increase after unilateral ovariectomy was not observed in the present study because we counted implantation sites rather than the number of ova released (Grady \& Greenwald, 1968; Joshi \& Labhsetwar, 1973). Draper (1965) found nearly complete compensation in the number of implantations in one strain of hamster but her data from the cream strain were similar to those of this study, indicating a possible strain difference.

We thank Ms Ellen M. Keough, Dr Paul I. Nelson, Dr John Ringo and Dr Jon Stanley for help with the statistical analyses and the preparation of the manuscript.

\section{References}

BANNergee, B.N. \& MASSIE, R.P. (1969) Regional differences with respect to blastocyst survival and implantation effected by locations of sutures in several regions of rat uterus. J. Reprod. Fert. 18, $527-529$.

Bo, W.J. \& KRUEGER, W.A. (1972) The antiimplantation effect of the polyethylene IUD in the rat. Contraception 5, 319-325.

Bo, W.J., Krueger, W.A. \& Garrison, B.M. (1972) The effect of the polyethylene IUD on rat embryogenesis. Contraception 6, 305-314.

Chang, C.C., Tatum, H.J. \& Kincl, F.A. (1970) The effect of intrauterine copper and other metals on implantations in rats and hamsters. Fert. Steril. 21, 274-278.

Corfman, P.A. \& Segal, S.J. (1968) Biological effects of intrauterine devices. Am. J. Obstet. Gynec. 100, $448-459$.

DRAPER, M.L. (1965) Uterine anatomical study and subsequently observed compensatory hypertrophy of ovarian tissue in the adult female hamster. Master's thesis, Bucknell University.

El Sahwi, S. \& MoYer, D.L. (1971) The leucocytic response to an intrauterine foreign body in the rabbit. Fert. Steril. 22, 398-408.

Grady, K.L. \& Greenwald, G.S. (1968) Studies on the interactions between the ovary and pituitary follicle stimulating hormone in the golden hamster. $J$. Endocr. 40, 85-90.

Greenwald, G.S. (1968) Influence of one or two ovaries on ovulation and ovarian weight in the hypophysectomized rat. Endocrinology 82, 591596.
Guenther, W.C. (1964) Analysis of Variance. Prentice Hall, Englewood Cliffs, New Jersey.

HoluB, W.R. (1972) Immunoglobulin G levels and use of immunosuppressives with an intrauterine device in the rat. Am. J. Obstet. Gynec. 114, 492-499.

Joshi, H.S. \& LABHSETWAR, A.P. (1973) The pattern of luteinizing hormone secretion after unilateral ovariectomy in cyclic hamsters. J. Endocr. 56, 153154.

MACKAY, S. \& BREed, W.G. (1972) Contraceptive effect of an intrauterine device in the mouse. J. Endocr. 55, xxxvii-xxxviii.

Marston, J.H. \& Kelly, W.A. (1969) The time and site of contraceptive action of an intrauterine device in the mouse. $f$. Endocr. 43, 83-93.

ORSINI, M.W. (1965) Effect of an intrauterine foreign body on the cycle and pregnancy in the hamster, Mesocricetus auratus Waterhouse. Anat. Rec. 15, $468-469$.

Peppler, R.D. (1971) Effects of unilateral ovariectomy on follicular development and ovulation in cycling and aged rats. Am. J. Anat. 132, 423-428.

Peppler, R.D. \& Greenwald, G.S. (1970) Influence of unilateral ovariectomy on follicular development in cycling rats. Am. J. Anat. 127, 9-14.

RICHARDSON, D.W. \& ANSBACHER, R. (1971) The effects of an intrauterine device on pregnancy in the golden hamster. J. Reprod. Fert. 25, 171-175.

Shulton, R.J., LoBl, R.T. \& WARD, P. (1975) Neutrophils and the mechanism of IUD action in rats. Fert. Steril. 26, 131-136.

WRENN, T.R., WoOD, J.R. \& BitMAN, J. (1968) A new technique for introducing IUDs into rat uteri. $J$. Reprod. Fert. 16, 515-517. 